JURNAL RISET MAHASISWA AKUNTANSI

http://ejournal.unikama.ac.id/index.php/jrma

JRMA, Volume 6, No 1, April 2018

\title{
Pengaruh Mekanisme Tata Kelola Perusahaan yang Baik, Pengungkapan Tanggung Jawab Sosial Perusahaan, dan Pengembalian atas Penggunaan Asset Terhadap Nilai Perusahaan
}

\author{
Anggi Adinda Setiarini \\ e-mail: adindaanggie09@gmail.com
}

\author{
Sulistyo \\ Rita Indah Mustikowati \\ (Program Studi Akuntansi, Fakultas Ekonomika dan Bisnis Universitas Kanjuruhan, \\ Malang)
}

\begin{abstract}
ABSTRAK
Penelitian ini bertujuan untuk mengetahui pengaruh mekanisme good corporate governance, corporate social responsibility disclosure, dan return on asset terhadap nilai perusahaan. Populasi yang digunakan dalam penelitian ini adalah perusahaan perbankan go public yang listed di Bursa Efek Indonesia periode 2014-2015 dan metode penentuan sampel yang digunakan adalah purposive judgement sampling. Sampel yang diperoleh sebanyak 42 perusahaan. Teknik analisis data yang digunakan adalah analisis deskriptif, uji asumsi klasik, uji regresi linear berganda, dan pengujian hipotesis. Penelitian ini menemukan bahwa secara simultan mekanisme good corporate governance corporate social responsibility disclosure, dan return on asset berpengaruh terhadap nilai perusahaan. Secara parsial penelitian ini menemukan bahwa mekanisme good corporate governance yang diproksikan oleh dewan direksi (DD), dewan komisaris (DK), kepemilikan manajerial (KM), return on asset (ROA) berpengaruh terhadap nilai perusahaan, sedangkan kepemilikan institusional (KI) dan corporate social responsibility (CSR) tidak berpengaruh terhadap nilai perusahaan. Kata Kunci: Dewan Direksi, Dewan Komisaris, Komite Audit, Kepemiikan Institusional, Kepemilikan Manajerial, Corporate Social Responsibility, Return on Assets, Nilai Perusahaan
\end{abstract}

\section{ABSTRACT}

This study aims to determine the effect of good corporate governance mechanisms, corporate social responsibility disclosure, and return on assets to firm value. The population used in this study is a publicly listed banking company listed on the Indonesia Stock Exchange in the 2014-2015 period and the sample determination method used was purposive judgment sampling. Samples obtained were 42 companies. Data analysis techniques used are descriptive analysis, classic assumption test, multiple linear regression test, and hypothesis testing. This study found that simultaneously the mechanism of good corporate governance, corporate social responsibility disclosure, and return on assets affect the value of the company. Partially, this study found that the mechanism of good corporate governance that was proxied by the board of directors (DD), board of commissioners (DK), managerial ownership (KM), return on assets (ROA) influenced the company value, while 
Anggi Adinda Setiarini, Pengaruh Mekanisme Tata Kelola Perusahaan yang Baik, Pengungkapan Tanggung Jawab Sosial Perusahaan, dan Pengembalian atas Penggunaan Asset Terhadap Nilai Perusahaan

institutional ownership (IC) and corporate social responsibility (CSR) does not affect the company's value

Keynotes: board of directors, board of commissioners, managerial ownership, Corporate Social Responsibility, Return on Assets, company's value

\section{PENDAHULUAN}

Nilai perusahaan yang tinggi menjadi keinginan para pemilik perusahaan sebab dengan nilai perusahaan yang tinggi menunjukkan tingkat kemakmuran pemegang saham juga tinggi. Nilai perusahaan yang tinggi akan membuat pasar percaya tidak hanya pada kinerja perusahaan saat ini namun juga pada prospek perusahaan di masa depan. Nilai perusahaan dipengaruhi oleh Good Corporate Governance (GCG) dan Corporate Social Responsibility Disclosure dan Return On Asset.

Menurut Herawaty (2008) menyatakan bahwa corporate governance merupakan cara atau mekanisme untuk memberikan keyakinan pada para pemasok dana perusahaan akan diperolehnya return atas investasi mereka. Dengan adanya mekanisme GCG ini diharapkan aktivitas monitoring terhadap manajer perusahaan dapat lebih efektif sehingga dapat meningkatkan nilai perusahaan.Menurut Murwaningsari (2009), Corporate Social Responsibility dalam prinsip Good Corporate Governance ibarat dua sisi mata uang, keduanya sama penting dan tidak dapat dipisahkan.

Corporate Social Responsibility (CSR) merupakan bentuk tanggung jawab perusahaan dalam memperbaiki kesenjangan social dan kerusakan lingkungan yang terjadi akibat aktivitas operasional perusahaan. Semakin banyak bentuk pertanggungjawaban yang dilakukan perusahaan terhadap lingkungannya, image perusahaan menjadi meningkat. Corporate Social Responsibility sebagai suatu komitmen bisnis untuk berkontribusi dalam pembangunan ekonomi berkelanjutan, bekerja dengan karyawan perusahaan, keluarga karyawan tersebut, berikut komunitas setempat dan masyarakat secara keseluruhan dalam rangka meningkatkan kualitas hidup yang mana ini perlu dipertimbangkan oleh perusahaan dalam upaya meningkatkan nilai perusahaan.

Return On Assets (ROA) adalah salah satu bentuk dari rasio profitabilitas yang dimaksudkan untuk mengukur kemampuan perusahaan atas keseluruhan dana yang ditanamkan dalam aktifitas yang digunakan untuk aktivitas operasi perusahaan dengan tujuan menghasilkan laba dengan memanfaatkan aktiva yang dimilikinya.

Tujuan penelitian ini adalah untuk menguji dan menjelaskan secara simultan mekanisme GCG, CSR Disclosure, ROA terhadap Nilai Perusahaan, serta menguji dan menjelaskan secara parsial Dewan Direksi, Dewan Komisaris, Komite Audit, Kepemilikan Institusional, Kepemilikan Manajerial, Corporate Social Responsibility, dan Return On Asset berpengaruh terhadap Nilai Perusahaan.

Berdasarkan latar belakang dan permasalahan diatas maka judul dalam penelitian ini adalah Pengaruh Mekanisme Good Corporate Governance,Corporate Social Responsibility Disclosure dan Return On Asset Terhadap Nilai Perusahaan yang terdaftar di Bursa Efek Indonesia (BEI) Tahun 2014-2015.

\section{TINJAUAN PUSTAKA}

Nilai perusahaan adalah nilai jual perusahaan atau nilai tumbuh bagi pemegang saham, nilai perusahaan akan tercermin dari harga pasar sahamnya. Nilai perusahaan dapat memberikan kemakmuran pemegang saham secara maksimum apabila harga saham perusahaan meningkat. Semakin tinggi nilai harga saham, maka makin tinggi 
Anggi Adinda Setiarini, Pengaruh Mekanisme Tata Kelola Perusahaan yang Baik, Pengungkapan Tanggung Jawab Sosial Perusahaan, dan Pengembalian atas Penggunaan Asset Terhadap Nilai Perusahaan

kemakmuran pemegang saham (Priantinah \& Retno, 2012). Kekayaan pemegang saham dan perusahaan dipresentasikan oleh harga pasar dari saham yang merupakan cerminan dari keputusan investasi, pendanaan (financing), dan manajemen assets (Hamdani, 2016 :139).

\section{Pengaruh Mekanisme GCG, CSR Disclosure, dan ROA terhadap Nilai Perusahaan}

Rustarini (2010) menyatakan bahwa perusahaan yang telah melaksanakan good corporate governance dengan baik sudah seharusnya melaksanakan aktivitas corporate social responsibility sebagai wujud kepedulian perusahaan kepada lingkungan sosial. Kedua kegiatan tersebut sama-sama bertujuan untuk mengoptimalkan nilai perusahaan bagi pemegang saham namun tetap memperhatikan pemangku kepentingan lainnya (Zarkasyi, 2008).

Oktaviani (2008) menyatakan bahwa dengan tingginya tingkat laba yang dihasilkan, berarti prospek perusahaan untuk menjalankan operasinya di masa depan juga tinggi sehingga nilai perusahaan yang tercermin dari harga saham perusahaan akan meningkat pula.

H1: Mekanisme GCG, CSR Disclosure, dan ROA berpengaruh terhadap Nilai Perusahaan

\section{Pengaruh Dewan Direksi terhadap Nilai Perusahaan}

Dewan Direksi mempunyai peran dan tanggung jawab yang penting dalam menentukan kebijakan yang akan dijalankan oleh perusahaan, baik dalam jangka waktu yang pendek maupun jangka waktu yang panjang. Pengawasan dilakukan oleh dewan komisaris dan direksi akan mencegah manajemen untuk melakukan tindakan yang dapat merugikan pemegang saham sehingga biaya atau kerugian akibat manajemen dapat berkurang. Dewan direksi merupakan mekanisme internal utama yang dapat melakukan monitoring terhadap manajer.

$\mathrm{H}_{2}$ : Dewan Direksi berpengaruh terhadap Nilai Perusahaan

\section{Pengaruh Dewan Komisaris terhadap Nilai Perusahaan}

Dewan komisaris dalam suatu perusahaan lebih ditekankan pengaruhnya pada fungsi monitoring dari implementasi kebijakan direksi. Peran dewan komisaris ini diharapkan dapat meminimalisir permasalahan yang terjadi di antara dewan direksi dengan pemegang saham. Oleh karena itu, dewan komisaris seharusnya dapat mengawasi kinerja direksi yang dihasilkan sesuai dengan kepentingan pemegang saham.

Dengan besarnya jumlah Dewan Komisaris disuatu perusahaan, pengawasan akan jauh lebih baik karena Dewan Komisaris dapat memberikan masukan atau opsi kepada Direksi (Bukhori dan Raharja, 2012).

$\mathrm{H}_{3}$ : Dewan Komisaris berpengaruh terhadap Nilai Perusahaan

\section{Pengaruh Komite Audit terhadap Nilai Perusahaan}

Komite audit yang efektif diperlukan dalam pencapaian Good Corporate Governance. Untuk membangun komite audit yang efektif maka prinsip dan landasan yang harus dipegang oleh komite audit meliputi independensi, transparansi dan disclousure, akuntabilitas dan tanggung jawab serta sikap yang adil. Adanya komite audit ini diharapkan dapat meningkatkan kualitas pengawasan internal perusahaan dan mampu mengoptimalkan mekanisme check and balance yang akhirnya akan ditujukan pada perlindungan yang optimum terhadap pemegang saham. (Susanto dan Subekti, 2013) $\mathrm{H}_{4}$ : Komite Audit berpengaruh terhadap Nilai Perusahaan 
Anggi Adinda Setiarini, Pengaruh Mekanisme Tata Kelola Perusahaan yang Baik, Pengungkapan Tanggung Jawab Sosial Perusahaan, dan Pengembalian atas Penggunaan Asset Terhadap Nilai Perusahaan

\section{Pengaruh Kepemilikan Institusional terhadap Nilai Perusahaan}

Kepemilikan institusional adalah persentase saham yang dimiliki oleh investor institusi seperti perusahaan asuransi, perusahaan investasi, dan bank (Moradi, 2012). Investor institusional dapat berperan dalam memonitor agen (manajer) perusahaan. Selain itu, investor institusional memiliki akses informasi yang lebih baik karena aktivitas investasi mereka, yang berarti pengetahuan yang lebih baik tentang kinerja perusahaan (Elili, 2011). Begitu pula menurut Wening (2009) semakin besar kepemilikan oleh institusi keuangan maka semakin besar pula kekuatan suara dan dorongan untuk mengoptimalkan nilai perusahaan.

H5: Kepemilikan Institusional berpengaruh terhadap Nilai Perusahaan

\section{Pengaruh Kepemilikan Manajerial terhadap Nilai Perusahaan}

Kepemilikan manajerial berperan sebagai pihak yang menyatukan kepentingan antara manajer dengan pemegang saham karena proporsi saham yang dimiliki manajer dan direksi mengindikasi menurunnya kecenderungan adanya tindakan manipulasi oleh manajemen (Purwaningtyas, 2011).

Penelitian Adnantara (2013) menemukan bukti bahwa kepemilikan manajerial tidak berpengaruh pada nilai perusahaan karena manajemen tidak mempunyai kendali terhadap perusahaan dan manajemen lebih banyak dikendalikan pemilik mayoritas.

$\mathrm{H}_{6}$ : Kepemilikan Manajerial berpengaruh terhadap Nilai Perusahaan

\section{Pengaruh Corporate Social Responsibility Disclosure terhadap Nilai Perusahaan}

Corporate Social Responsibility atau tanggung jawab sosial perusahaan adalah bentuk pertanggungjawaban yang berupa informasi yang disampaikan dalam laporan tahunan perusahaan mengenai tanggung jawab perusahaan atas kegiatan operasi perusahaan tersebut kepada masyarakat. Tanggung jawab sosial perusahaan merupakan komitmen perusahaan atau dunia bisnis untuk berkontribusi dalam pembangunan ekonomi yang berkelanjutan dengan menitik beratkan pada keseimbangan antara perhatian terhadap aspek ekonomi, sosial, dan lingkungan (Priyanto, 2008).

$\mathrm{H}_{7}$ : Corporate Social Responsibility berpengaruh terhadap Nilai Perusahaan

\section{Pengaruh Return On Asset terhadap Nilai Perusahaan}

Para investor melakukan overview suatu perusahaan dengan melihat rasio keuangan sebagai alat evaluasi investasi, karena rasio keuangan mencerminkan tinggi rendahnya nilai perusahaan. Jika investor ingin melihat seberapa besar perusahaan menghasilkan return atas investasi yang akan mereka tanamkan, yang akan dilihat pertama kali adalah rasio profitabilitas. Penelitian yang dilakukan oleh Aisyatul Munawaroh (2014) menemukan hasil bahwa Return On Assets berpengaruh negatif signifikan terhadap nilai perusahaan. Oleh karena itu, Return On Assets merupakan salah satu faktor yang berpengaruh terhadap nilai perusahaan.

$\mathrm{H}_{8}$ : Return On Asset berpengaruh terhadap Nilai Perusahaan 
Anggi Adinda Setiarini, Pengaruh Mekanisme Tata Kelola Perusahaan yang Baik, Pengungkapan Tanggung Jawab Sosial Perusahaan, dan Pengembalian atas Penggunaan Asset Terhadap Nilai Perusahaan

Dapat digambarkan kerangka konseptual pada gambar seperti berikut:

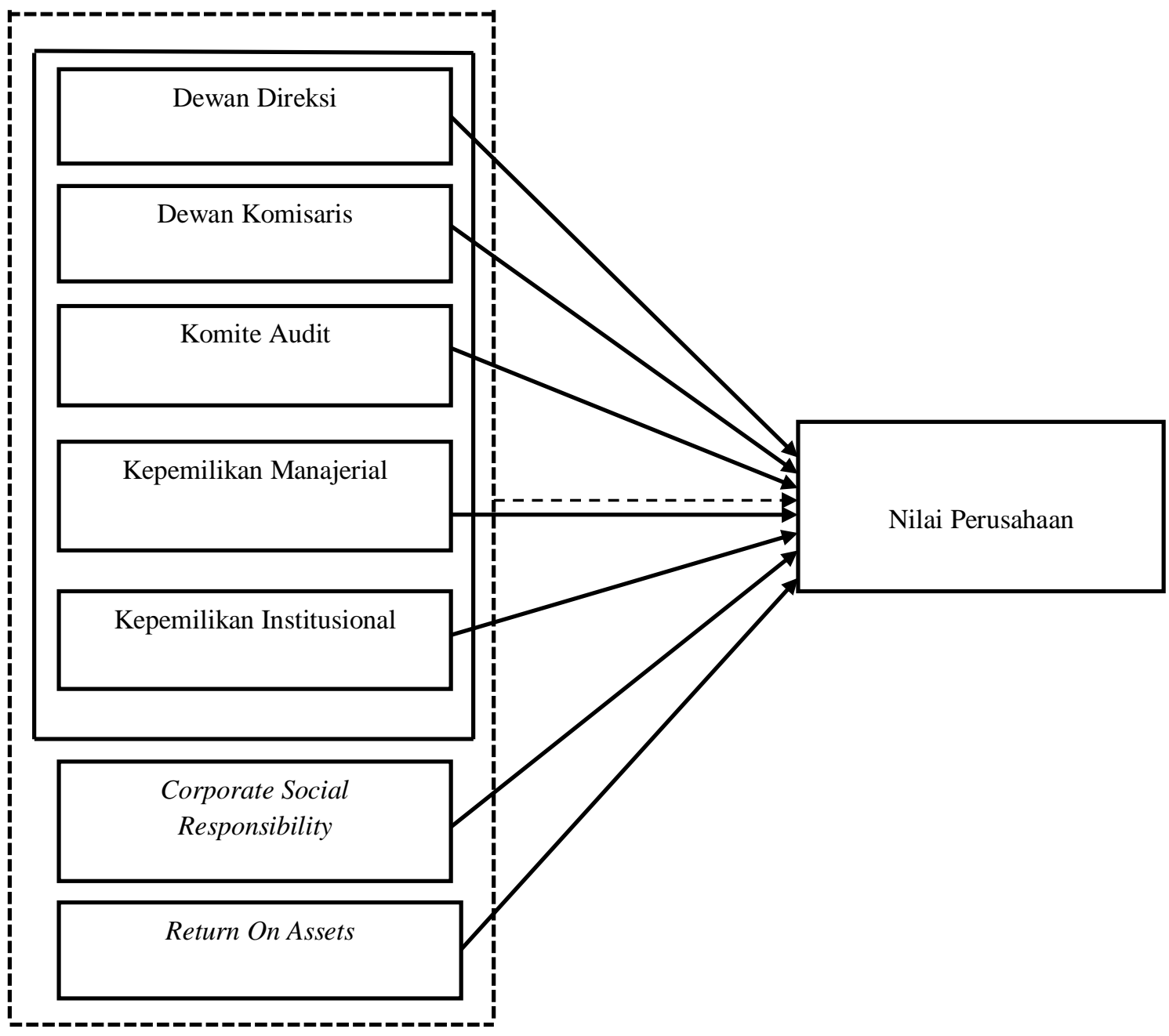

Gambar 2.1.3

Kerangka Konseptual

\section{METODE}

Jenis penelitian yang digunakan adalah explanatory research, yaitu menjelaskan hubungan kausal antara variabel-variabel penelitian melalui pengujian. Penelitian ini menggunakan metode penelitian kuantitatif. Metode penelitian kuantitatif dapat diartikan sebagai metode penelitian yang berlandaskan pada filsafat positivisme, digunakan untuk meneliti pada populasi atau sampel tertentu, pengumpulan data menggunakan instrument penelitian, analisis data bersifat kuantitatif atau statistik, dengan tujuan untuk menguji hipotesis yang telah ditetapkan (Sugiyono, 2012:88). Berupa laporan tahunan perusahaan perbankan periode 2014-2015, yang diperoleh dari situs BEI yang di akses melalui www.idx.co.id serta studi pustaka, jurnal dan lain-lain.

Teknik pengambilan sampel dalam penelitian ini menggunakan purposive sampling. Purposive sampling yaitu sampel yang dipilih dengan menggunakan pertimbangan tertentu 
Anggi Adinda Setiarini, Pengaruh Mekanisme Tata Kelola Perusahaan yang Baik, Pengungkapan Tanggung Jawab Sosial Perusahaan, dan Pengembalian atas Penggunaan

Asset Terhadap Nilai Perusahaan

yang disesuaikan dengan tujuan penelitian. Adapun kriteria sampel yang digunakan adalah sebagai berikut :

1. Perusahaan perbankan yang telah go public di Bursa Efek Indonesia pada kurun waktu penelitian (periode 2014-2015)

2. Bank yang mempublikasikan ringkasan kinerja di Bursa Efek Indonesia berturutturut (periode 2014-2015)

3. Perusahaan perbankan yang mempublikasikan laporan keuangan tahunan (annual report) secara lengkap periode 2014-2015 yang dinyatakan dalam rupiah.

\section{Definisi operasional dan pengukuran variabel}

Variabel dependen pada penelitian ini adalah nilai perusahaan. Nilai perusahaan disimbolkan dengan (Y). Nilai perusahaan pada setiap perusahaan berbeda, sesuai dengan kemampuan perusahaan yang dilihat dari nial jual perusahaan atau nilai tumbuh perusahaan bagi pemegang saham yang tercermin dari harga pasar saham, sehingga akan memberi kemakmuran bagi pemegang saham secara maksimal, jika harga perusahaan meningkat. Nilai perusahaan adalah sebagai varaibel dependen memiliki karakteristik dimana besar kecilnya dipengaruhi oleh banyak faktor. Dengan kata lain, pertumbuhan nilai perusahaan bergantung pada perusahaan satu atau lebih faktor. Variabel ini digunakan oleh Rika dan Islahuddin (2008).

$$
\mathrm{Q}=\frac{(\mathrm{EMV}+\mathrm{D})}{(\mathrm{EBV}+\mathrm{D})}
$$

Variabel independen adalah variabel yang menjelaskan atau mempengaruhi variabel yang lain. Penelitian ini menggunakan variabel mekanisme good corporate governance dan profitabilitas perusahaan sebagai variabel independen. Berikut ini merupakan penjelasan dari variabel independen:

Dewan direksi adalah organ perseroan yang berwenang dan memiliki tanggung jawab yang besar terhadap kepengurusan bank. Dewan Direksi diukur dengan jumlah anggota yang ada dalam perusahaan. Menurut Peraturan Bank Indonesia No 8/4/2006 tentang pelaksanaan Good Corporate Governance, jumlah anggota dewan direksi minimal 3 orang. Keadaan dewan direksi tersebut bertugas sebagai mekanisme pengendali internal untuk memonitor para manajer perusahaan. Maka ukuran dewan direksi diukur dengan (Fitrianingsih, 2015)

\section{Dewan Direksi $=\Sigma$ Anggota Dewan Direksi}

Dewan komisaris merupakan jumlah anggota dewan komisaris dalam suatu perusahaan, yaitu komisaris utama, komisaris utama dan komisaris independen. Variable ukuran dewan komisaris dihitung dari jumlah nominal anggota dewan komisaris yang tercantum dalam laporan keuangan tahunan. Variable ukuran dewan komisaris dilambangkan dengan DKOM (Fitrianingsih, 2015):

Dewan Komisaris $=\sum$ Anggota Dewan Komisaris

Komite Audit adalah suatu komite yang dibentuk oleh dewan komisaris dan memiliki tugas dan tanggung jawab untuk melakukan pengawasan terhadap laporan keuangan, audit eksternal dan mengamati sistem pengendalian internal. Variabel komite audit diukur dengan melihat jumlah anggota komite audit yang terdapat di perbankan 
Anggi Adinda Setiarini, Pengaruh Mekanisme Tata Kelola Perusahaan yang Baik, Pengungkapan Tanggung Jawab Sosial Perusahaan, dan Pengembalian atas Penggunaan Asset Terhadap Nilai Perusahaan tersebut . Komite audit dihitung dari jumlah anggota komite audit yang dimiliki (Abdillah, 2016).

$$
\text { Komite Audit }=\Sigma \text { Anggota Komite Audit }
$$

Kepemilikan Institusional (institusional ownership) merupakan persentase kepemilikan saham perusahaan yang dimiliki investor institusional seperti pemerintah, perusahaan investasi, bank, perusahaan asuransi, maupun kepemilikan lembaga dan perusahaan lain. Kepemilikan institusional diukur dengan persentase kepemilikan institusi dalam struktur saham perusahaan (Juniarti 2009).

$$
\mathrm{IO}=\frac{\text { Jumlah lembar saham yang dimiliki institusi }}{\text { Total lembar saham yang beredar }} \times 100 \%
$$

Kepemilikan Manajerial (manajerial ownership) adalah pemegang saham dari pihak manajemen yanag secara aktif ikut dalam pengambilan keputusan. Kepemilikan Manajerial merupakan suatu kondisi di mana pihak manajemen perusahaan memiliki rangkap jabatan yaitu jabatannya sebagai manajemen perusahaan dan juga pemegang saham dan berperan aktif dalam pengambilan keputusan yang dilaksanakan (Frysa Pradhita, 2010).

$$
\mathrm{MO}=\frac{\text { Jumlah lembar saham yang dimiliki manajemen }}{\text { Total lembar saham yang beredar }} \times 100 \%
$$

\section{Teknik Analisis Data}

\section{Pengujian asusmsi klasik}

\section{Uji Normalitas}

Uji normalitas bertujuan untuk mengetahui apakah dalam model regresi variabel penganggu memiliki distribusi normal. Serpeti diketahui bahwa uji $\mathrm{t}$ dan $\mathrm{F}$ mengasumsikan bahwa nilai residual mengikuti distribusi normal. Jika asumsi ini dilanggar maka uji statistik menjadi tidak valid untuk jumlah sampel kecil. , uji normalitas juga dapat diuji dengan statistik non-parametrik Kolmogorov Smirnov (K-S) dengan menggunakan taraf signifikansi 5\%. Jika, signifikansi (dapat dilihat pada Asymp. Sig. (2-tiled) pada output SPSS) dari nilai Kolmogorov Smirnov $>5 \%$, data yang digunakan berdistribusi normal (Ghozali, 2013).

\section{Uji Multikolinieritas}

Uji multikolinearitas merupakan syarat yang digunakan dalam analisis regresi berganda yang digunakan untuk mengkaji ada korelasi atau tidak ada korelasi antar variabel independen. Model regresi yang baik seharusnya tidak terjadi korelasi antar variabel independen (Umar, 2011). Multikolinearitas dalam model regresi dapat dilihat dari nilai variance inflation factor (VIF). Apabila nilai VIF lebih besar dari satu (VIF $>10$ ) menunjukkan adanya gejala multikolinearitas. Sedangkan, nilai VIF yang mendekati satu menunjukkan tidak adanya gejala multikolinearitas (Ghozali, 2013).

Uji Autokorelasi

Uji autokorelasi bertujuan untuk mengetahui hubungan yang kuat baik positif maupun negatif atau tidak ada hubungan antar data yang ada pada variabel-variabel penelitian dalam model regresi linier. Pengujian adanya autokolerasi dapat dilakukan menggunakan uji Durbin-Watson Test. Tidak terjadi autokorelasi, jika nilai DW berada diantara 1,55 -2,46 atau 1,55 $\leq \mathrm{DW} \leq 2,46$ (Ghozali, 2013). 
Anggi Adinda Setiarini, Pengaruh Mekanisme Tata Kelola Perusahaan yang Baik, Pengungkapan Tanggung Jawab Sosial Perusahaan, dan Pengembalian atas Penggunaan Asset Terhadap Nilai Perusahaan

\section{Uji Heteroskedastisitas}

Uji heteroskedastisitas bertujuan untuk menguji dalam model regresi terjadi kesaman atau ketidaksamaan varian dari residual satu pengamatan kepengamatan yang lain. Jika variansi dari residual satu pengamatan ke pengamatan lain tetap maka disebut homoskedastisitas dan jika berbeda disebut heteroskedasitas. Jika plot menyebar secara terpencar dan tidak membentuk pola tertentu maka dapat disimpulkan bahwa tidak terjadi masalah heteroskedastisitas (Ghozali, 2013).

\section{Analisis Regresi Linier Berganda}

Analisis linier berganda digunakan untuk mengetahui arah hubungan antara variabel independen dengan variabel dependen, apakah masing-masing variabel independen berhubungan positif atau negatif dan untuk memprediksi nilai dari variabel dependen apabila nilai variabel independen mengalami kenaikan atau penurunan. (Sugiyono, 2010). Persamaan regresi linier berganda dapat dinyatakan sebagai berikut:

$$
Y=\beta_{0}+\beta_{1} X_{1}+\beta_{2} X_{2}+\beta_{3} X_{3}+\beta_{4} X_{4}+\beta_{5} X_{5}+\beta_{6} X_{6}+\beta_{7} X_{7}+\varepsilon
$$

Keterangan :

$\mathrm{Y}=$ Variabel peringkat obligasi dengan delapan kategori

$\beta_{0}=$ Konstanta

$\beta_{1}=$ Dewan Direksi

$\beta_{2}=$ Dewan Komisaris

$\beta_{3}=$ Komite Audit

$\beta_{4}=$ Kepemilikan Konstitusional

$\beta_{5}=$ Kepemilikan Manajerial

$\beta_{6}=$ Corporate Social Responsibility

$\beta_{7}=$ Return On Asset

$\varepsilon \quad=$ Standard Error

(Sumber : Pengembangan dari berbagai sumber)

\section{Koefisien Determinasi Ganda $\left(\mathbf{R}^{2}\right)$}

Koefisien Determinasi (R2) digunakan untuk mengetahui seberapa jauh kemampuan suatu model penelitian dalam menjelaskan variasi variabel dependen yang ada. Dengan demikian akan diketahui seberapa besar variabel dependen dapat diterangkan oleh variabel independen yang ada. Nilai yang medekati angka 1 berarti variabel independen hampir atau mampu memberikan informasi yang dibutuhkan untuk memprediksi variasi dependen (Ghozali, 2013).

\section{Pengujian Hipotesis}

1. Uji Parsial (Uji-F)

Uji F dilakukan untuk mengatahui apakah variabel dependen secara bersama-sama dipengaruhi oleh variabel independen. Pengujian dapat dilakukan dengan melihat tingkat signifikansi F. Menurut Ghozali (2013) hipotesis dapat diterima dan ditolak dengan melihat keriteria sebagai berikut:

a. Jika nilai signifikansi lebih besar dari 5\% maka hipotesis ditolak

b. Jika nilai signifikansi lebih kecil dari 5\% maka hipotesis diterima

2. $\quad$ Uji Parsial (Uji-T) 
Anggi Adinda Setiarini, Pengaruh Mekanisme Tata Kelola Perusahaan yang Baik, Pengungkapan Tanggung Jawab Sosial Perusahaan, dan Pengembalian atas Penggunaan

Asset Terhadap Nilai Perusahaan

Uji ini dilakukan untuk mengetahui seberapa jauh variabel independen secara individu dalam menerangkan variabel dependen. Uji statistik $\mathrm{t}$ digunakan untuk mengetahui apakah ada perbedaan yang terjadi antara variabel-variabel uji terhadap kelompok uji. Menurut Ghozali (2013) hipotesis dapat diterima dan ditolak dengan melihat keriteria sebagai berikut:

a. Jika nilai signifikansi lebih besar dari 0,05 maka hipotesis ditolak

b. Jika nilai signifikansi lebih kecil dari 0,05 maka hipotesis diterima.

\section{HASIL DAN PEMBAHASAN}

\section{Hasil Analisis Deskriptif}

Nilai Perusahaan

Rata-rata Nilai Perusahaan untuk tahun 2014 sebesar 1,05\% tahun dan tahun 2015 sebesar 1,01\%. Kemudian nilai tertinggi dari Nilai Perusahaan untuk tahun 2014-2015 adalah BBCA (Bank Central Asia Tbk) dengan tahun 2014 sebesar 1,44\%, dan tahun 2015 sebesar $1,39 \%$. Semakin besar nilai perusahaan akan baik untuk investor menanamkan modal saham di perusahaan tersebut. Selanjunya nilai terendah dari Nilai Perusahaan adalah PNBS (Bank Pan Indonesia Syariah Tbk) untuk tahun 2014 sebesar 0,43\% dan tahun 2015 sebesar 0,46. Semakin rendah nilai perusahaan investor tidak akan menanamkan modal sahamnya di perusahaan tersebut.

Dewan Direksi

Rata-rata jumlah Dewan Direksi untuk tahun 2014 sebesar 5,90\% dan tahun 2015 sebesar 6,05\%. Kemudian nilai tertinggi dari jumlah Dewan Direksi diperoleh oleh BBRI (Bank BRI Tbk) untuk tahun 2014 sebesar 10\%, tahun 2015 sebesar 9\%. Artinya semakin besar jumlah DD maka semakin baik untuk meningkatkan nilai perusahaan. Selanjutnya nilai terendah dari jumlah Dewan Direksi diperoleh oleh BMAS (Bank Maspion Indonesia Tbk) untuk tahun 2014 sebesar 2\% dan tahun 2015 sebesar 2\%. Artinya apabila jumlah DD sedikit, mengindikasikan bahwa semakin rendah upaya untuk meningkatkan nilai perusahaan.

\section{Dewan Komisaris}

Rata-rata jumlah Dewan Komisaris untuk tahun 2014 sebesar 1,67\% dan tahun 2015 sebesar 1,76\%. Kemudian nilai tertinggi dari jumlah Dewan Komisaris untuk tahun 2014-2015 adalah BBNI (Bank Negara Indonesia Tbk), BTPN (Bank Tabungan Pensiunan Nasional Tbk), dan NISP (Bank NISP OCBC Tbk) yaitu sebesar 3\%. Artinya semakin besar jumlah DK memungkinkan untuk mengelola perusahaan dengan baik dan juga akan meningkatkan nilai perusahaan. Selanjunya nilai terendah dari jumlah Komite Audit untuk tahun 2014-2015 adalah 1\% yaitu BBCA (Bank Central Asia Tbk), BBNP (Bank Nusantara Parahyangan Tbk), BMAS (Bank Maspion Indonesia Tbk), BVIC (Bank Victoria Internasional Tbk), INPC (Bank Artha Graha Indonesia Tbk), MEGA (Bank Mega Tbk), PNBN (Bank Pan Indonesia Tbk), PNBS (Bank Pan Indonesia Syariah Tbk). Artinya apabila jumlah DK sedikit, mengindikasikan bahwa semakin rendah pengawasan yang dimiliki perusahaan dalam melihat kinerja para direksi.

Komite Audit

Rata-rata Komite Audit untuk tahun 2014 sebesar 2,86\% dan tahun 2015 sebesar 2,81\%. Kemudian nilai tertinggi dari Komite Audit untuk tahun 2014-2015 sebesar 5\% yaitu INPC (Bank Artha Graha Indonesia Tbk). Artinya semakin banyak jumlah KA maka semakin baik kinerja dalam perusahaan. Selanjutnya nilai terendah dari Komite Audit tahun 2014-2015 sebesar 2\% yaitu AGRO (Bank Rakyat Indonesia Agroniaga Tbk), BBCA (Bank Central Asia Tbk), BBNP (Bank Nusantara Parahyangan Tbk), BDMN (Bank 
Anggi Adinda Setiarini, Pengaruh Mekanisme Tata Kelola Perusahaan yang Baik, Pengungkapan Tanggung Jawab Sosial Perusahaan, dan Pengembalian atas Penggunaan

Asset Terhadap Nilai Perusahaan

Danamon Indonesia Tbk), BJTM (Bank Pembangungan Daerah Jawa Timur Tbk), BNLI (Bank Permata Tbk), MEGA (Bank Mega Tbk), dan PNBS (Bank Pan Indonesia Syariah Tbk). Artinya apabila jumlah KA sedikit, mengindikasikan bahwa semakin rendah kinerja dalam perusahaan..

Kepemilikan Institusional

Rata-rata Kepemilikan Institusional untuk tahun 2014 sebesar 72,84\% dan tahun 2015 sebesar 73,89\%. Kemudian nilai tertinggi dari Kepemilikan Institusional untuk tahun 2014-2015 sebesar 97,29\% yaitu BNII (Bank Maybank Indonesia Tbk). Artinya semakin tinggi KI maka semakin baik dalam tata kelola perusahaan dan akan meningkatkan nilai perusahaan. Selanjutnya nilai terendah dari Kepemilikan Institusional tahun 2014-2015 sebesar 47,15\% yaitu BBCA (Bank Central Asia Tbk). Artinya apabila KI rendah, mengindikasikan bahwa semakin rendah kinerja perusahaan sehingga tidak dapat untuk meningkatkan nilai perusahaan.

\section{Kepemilikan Manajerial}

Rata-rata Kepemilikan Manajerial untuk tahun 2014 sebesar 24,65\% dan tahun 2015 sebesar 23,81\%. Kemudian nilai tertinggi dari Kepemilikan Manajerial untuk tahun 2014-2015 sebesar 52,85\% yaitu BBCA (Bank Central Asia Tbk). Semakin tinggi KM maka semakin baik kinerja manajer dalam mengelola perusahaan serta meniningkatkan nilai perusahaan. Selanjutnya nilai terendah dari Kepemilikan Institusional tahun 2014-2015 sebesar 2,25\% yaitu BBNI (Bank Negara Indonesia Tbk). Artinya apabila KM rendah, mengindikasikan bahwa semakin rendah kepemilikan saham perusahaan yang dimiliki oleh pihak manajemen.

\section{Corporate Social Responsibility}

Rata-rata Corporate Social Responsibility untuk tahun 2014 sebesar 0,12\% dan tahun 2015 sebesar 0,13\%. Kemudian nilai tertinggi dari Corporate Social Responsibility untuk tahun 2014 sebesar 0,23\% yaitu oleh BBCA (Bank Central Asia Tbk) dan tahun 2015 sebesar 0,27\% yaitu oleh BJTM (Bank Pembangunan Daerah Jawa Timur Tbk). Artinya semakin tinggi CSR maka tanggung jawab sosial perusahaan sebagian besar telah diungkapkan dalam perusahaan. Selanjutnya nilai terendah dari Corporate Social Responsibility tahun 2014-2015 sebesar 0,01\% yaitu BTPN (Bank Tabungan Pensiunan Nasional Tbk). Artinya semakin rendah CSR berarti perusahaan tersebut tidak mengungkapkan tanggung jawab sosial perusahaan.

\section{Return On Asset}

Rata-rata Return On Asset untuk tahun 2014-2015 sebesar 0,01\%. Kemudian nilai tertinggi dari Return On Asset untuk tahun 2014 dan tahun 2015 sebesar 0,03\% yaitu oleh BBCA (Bank Central Asia Tbk). Artinya semakin tinggi return on asset maka semakin efisien untuk memperoleh laba dan semakin baik dalam membayar hutang perusahaan. Selanjutnya nilai terendah dari Return On Asset tahun 2014-2015 sebesar 0,00\% yaitu NOBU (Bank Naasionalnobu Tbk). Artinya semakin rendah return on asset, mengindikasikan semakin kecil pula tingkat keuntungan yang dicapai suatu perusahaan.

\section{Hasil Uji Asumsi Klasik}

\section{Hasil Uji Asmsi Klasik Normalitas}

Hasil uji asumsi klasik normalitas dengan pendekatan kolmogorov-smirnov . Hasil disajikan pada tabel 4.13 Nilai signifikan kolmogorof-smirnov dengan melihat Asmp Sig, suatu data dinyatakan berdistribusi normal jika nilai asymp sig (2-tailed) hasil pengujian Kolmogorov-smirnov lebih besar dari 0.05 atau 5\%. Nilai asymp sig sebesar 0.080 melebihi 0.05 (5\%). Ini berarti bahwa data variabel penggangu memiliki distribusi normal. Hasil Uji Asumsi Klasik Multikolinieritas 
Anggi Adinda Setiarini, Pengaruh Mekanisme Tata Kelola Perusahaan yang Baik, Pengungkapan Tanggung Jawab Sosial Perusahaan, dan Pengembalian atas Penggunaan Asset Terhadap Nilai Perusahaan

Hasil uji asumsi klasik multikolinieritas dengan VIF (Variance Inflation Factor) disajikan dan diringkas pada tabel 4.11 berikut:

Tabel 4.11

Hasil Uji Asumsi Klasik Multikolinieritas

\begin{tabular}{|c|c|c|c|}
\hline Variabel & Nilai VIF & Kriteria & Simpulan \\
\hline X1_DD & 2.502 & $<10$ & Tidak terjadi multikolinieritas \\
\hline X2_DK & 2.019 & $<10$ & Tidak terjadi multikolinieritas \\
\hline X3_KA & 1.326 & $<10$ & Tidak terjadi multikolinieritas \\
\hline X4_KI & 4.802 & $<10$ & Tidak terjadi multikolinieritas \\
\hline X5_KM & 4.546 & $<10$ & Tidak terjadi multikolinieritas \\
\hline X6_CSR & 1.407 & $<10$ & Tidak terjadi multikolinieritas \\
\hline X7_ROA & 1.738 & $<10$ & Tidak terjadi multikolinieritas \\
\hline
\end{tabular}

Sumber: data sekunder diolah peneliti tahun 2017

Hasil Uji Asumsi Klasik Autokorelasi

Hasil uji autokorelasi menggunakan pendekatan Durbin Watson nampak bahwa nilainya sebesar 1.910 terletak di antara 1,55 - 2,46. Dengan demikian tidak terjadi autokorelasi.

Hasil Uji Asumsi Klasik Heteroskedastisitas

Hasil pengujian Heteroskedastisitas pada gambar 4.12, dimana sebaran data tidak membentuk pola tertentu dan titik-titik menyebar di atas dan dibawah angka 0 pada sumbu Y. Pada pola gambar Scatterplot di atas terlihat bahwa titik-titik menyebar secara acak, baik di bagian atas angka 0 atau di bagian bawah angka 0 dari sumbu vertikal atau sumbu Y, demikian maka tidak terjadi heteroskedastisitas dalam model regresi ini.

\section{Hasil Analisis Regresi Linier Berganda}

Hasil analisi regresi linier berganda disajikan pada lampiran 2. Dari lampiran tersebut dapat dibuat persamaan regresi sebagai berikut:

$$
\begin{aligned}
\mathrm{Y}=\beta_{0}+ & \beta_{1} \mathrm{X}_{1}+\beta_{2} \mathrm{X}_{2}+\beta_{3} \mathrm{X}_{3}+\beta_{4} \mathrm{X}_{4}+\beta_{5} \mathrm{X}_{5}+\beta_{6} \mathrm{X}_{6}+\beta_{7} \mathrm{X}_{7}+\varepsilon \\
\mathrm{NP}= & 1.967+0.254 \mathrm{DD}-0.399 \mathrm{DK}+0.180 \mathrm{KA}-0.248 \mathrm{KI}-0.265 \mathrm{KM}+0.002 \mathrm{CSR}+ \\
& 0.194 \mathrm{ROA}+0.456
\end{aligned}
$$

Tabel 4.9

Ringkasan Hasil Analisis Regresi

\begin{tabular}{|l|r|r|c|}
\hline \multicolumn{1}{|c|}{ Variabel } & \multicolumn{1}{c|}{$\begin{array}{c}\text { Koefisisen } \\
\text { Regresi }\end{array}$} & $\begin{array}{c}\text { Nilai } \\
\text { Signifikansi }\end{array}$ & Kesimpulan \\
\hline Variabel X1 (DD) & 0.254 & 0,006 & Berpengaruh \\
\hline Variabel X2 (DK) & -0.399 & 0,000 & Berpengaruh \\
\hline Variabel X3 (KA) & 0.180 & 0,008 & Berpengaruh \\
\hline Variabel X4 (KI) & -0.248 & 0,053 & Tidak Berpengaruh \\
\hline Variabel X5 (KM) & -0.265 & 0,034 & Berpengaruh \\
\hline Variabel X6 (CSR) & -0.002 & 0.976 & Tidak Berpengaruh \\
\hline Variabel X7 (ROA) & 0.194 & 0.012 & Berpengaruh \\
\hline
\end{tabular}

Sumber: data sekunder diolah peneliti tahun 2017

Berdasarkan pada persamaan tabel 4.9 dapat dijelaskan sebagai berikut: 
Anggi Adinda Setiarini, Pengaruh Mekanisme Tata Kelola Perusahaan yang Baik, Pengungkapan Tanggung Jawab Sosial Perusahaan, dan Pengembalian atas Penggunaan Asset Terhadap Nilai Perusahaan

1. Koefisien $X_{1}=0,254$. Hal ini mengindikasikan bahwa variabel Dewan Direksi berhubungan positif dengan nilai perusahaan. Jika variabel Dewan Direksi dinaikkan 1 satuan, maka nilai perusahaan akan turun 0,254 persen.

2. Koefisien $X_{2}=-0,399$. Hal ini mengindikasikan bahwa variabel Dewan Komisaris berhubungan negatif dengan nilai perusahaan. Jika variabel volume ditingkatkan 1 satuan, maka nilai perusahaan akan turun $-0,399$ persen

3. Koefisien $X_{3}=0,180$. Hal ini mengindikasikan bahwa variabel Komite Audit berhubungan positif dengan nilai perusahaan. Jika variabel Dewan Direksi dinaikkan 1 satuan, maka nilai perusahaan akan turun 0,180 persen.

4. Koefisien $\mathrm{X}_{4}=-0.248$. Hal ini mengindikasikan bahwa variabel Kepemilikan Institusional berhubungan negatif dengan nilai perusahaan. Jika variabel volume ditingkatkan 1 satuan, maka nilai perusahaan akan turun -0,248 persen.

5. Koefisien $X_{5}=-0,265$. Hal ini mengindikasikan bahwa variabel Kepemilikan Manajerial berhubungan negatif dengan nilai perusahaan. Jika variabel volume ditingkatkan (semakin tidak efisien) 1 satuan, maka nilai perusahaan akan turun 0,265 persen

6. Koefisien $\mathrm{X}_{6}=0,002$. Hal ini mengindikasikan bahwa variabel Corporate Social Responsibility berhubungan positif dengan nilai perusahaan. Jika variabel Corporate Social Responsibility dinaikkan 1 satuan, maka nilai perusahaan akan turun 0,002 persen.

7. Koefisien $\mathrm{X}_{7}=0,194$. Hal ini mengindikasikan bahwa variabel Return On Asset berhubungan positif dengan nilai perusahaan. Jika variabel Return On Asset dinaikkan 1 satuan, maka nilai perusahaan akan turun 0,194 persen.

\section{Hasil Uji Hipotesis}

\section{Hasil Uji Hipotesis Pertama}

Nilai signifikansi uji-F variabel Dewan Direksi, Dewan Komisaris, Komite Audit, Kepemilikan Institusional, Kepemilikan Manajerial, Corporate Social Responsibility, dan Return On Asset sebesar 0,000 lebih kecil alpa 5\%. Hal ini berarti bahwa secara simultan variabel Dewan Direksi, Dewan Komisaris, Komite Audit, Kepemilikan Institusional, Kepemilikan Manajerial, Corporate Social Responsibility, dan Return On Asset berpengaruh terhadap variabel Nilai Perusahaan. Dengan demikian, hipotesis pertama yang menyatakan bahwa variabel dewan direksi, dewan komisaris, komite audit, kepemilikan institusional, kepemilikan manajerial, corporate social responsibility, dan return on asset berpengaruh terhadap nilai perusahaan diterima.

\section{Hasil Uji Hipotesis Kedua}

Nilai signifikansi uji-t atas variabel Dewan Direksi sebesar 0,006 lebih kecil alpa $5 \%$. Hal ini berarti bahwa secara parsial variabel Dewan Direksi berpengaruh terhadap variabel Nilai Perusahaan. Dengan demikian, hipotesis kedua yang menyatakan bahwa dewan direksi berpengaruh terhadap nilai perusahaan diterima.

\section{Hasil Uji Hipotesis Ketiga}

Nilai signifikansi uji-t variabel Dewan Komisaris sebesar 0,000 lebih kecil alpa 5\%. Hal ini berarti bahwa secara parsial variabel Dewan Komisaris berpegaruh terhadap variabel Nilai Perusahaan. Dengan demikian, hipotesis ketiga yang menyatakan bahwa dewan komisaris berpengaruh terhadap nilai perusahaan diterima.

Hasil Uji Hipotesis Keempat 
Anggi Adinda Setiarini, Pengaruh Mekanisme Tata Kelola Perusahaan yang Baik, Pengungkapan Tanggung Jawab Sosial Perusahaan, dan Pengembalian atas Penggunaan

Asset Terhadap Nilai Perusahaan

Nilai signifikansi uji-t variabel Komite Audit sebesar 0,008 lebih kecil alpa 5\%. Hal ini berarti bahwa secara parsial variabel Komite Audit berpengaruh terhadap variabel Nilai Perusahaan. Dengan demikian, hipotesis keempat yang menyatakan bahwa variabel komite audit berpengaruh terhadap nilai perusahaan diterima.

Hasil Uji Hipotesis Kelima

Nilai signifikansi uji-t variabel Kepemilikan Institusional sebesar 0,053 lebih besar alpa 5\%. Hal ini berarti bahwa secara parsial variabel Kepemilikan Institusional tidak berpengaruh terhadap variabel Nilai Perusahaan. Dengan demikian, hipotesis kelima yang menyatakan bahwa variabel kepemilikan insttitusional berpengaruh terhadap nilai perusahaan ditolak.

Hasil Uji Hipotesis Keenam

Nilai signifikansi uji-t variabel Kepemilikan Manajerial sebesar 0,034 lebih kecil alpa 5\%. Hal ini berarti bahwa secara parsial variabel Kepemilikan Manajerial berpengaruh terhadap variabel Nilai Perusahaan. Dengan demikian, hipotesis keenam yang menyatakan bahwa variabel kepemilikan manajerial berpengaruh terhadap nilai perusahaan diterima.

Hasil Uji Hipotesis Ketujuh

Nilai signifikansi uji-t variabel Corporate Social Responsibility sebesar 0,976 lebih besar alpa 5\%. Hal ini berarti bahwa secara parsial variabel Corporate Social Responsibility tidak berpengaruh terhadap variabel Nilai Perusahaan. Dengan demikian, hipotesis ketujuh yang menyatakan bahwa variabel Corporate Social Responsibility berpengaruh terhadap nilai perusahaan ditolak.

Hasil Uji Hipotesis Kedelapan

Nilai signifikansi uji-t variabel Return On Asset sebesar 0,012 lebih kecil alpa 5\%. Hal ini berarti bahwa secara parsial variabel Return On Asset berpengaruh terhadap variabel Nilai Perusahaan. Dengan demikian, hipotesis kedelapan yang menyatakan bahwa variabel Return On Asset berpengaruh terhadap nilai perusahaan diterima.

\section{KESIMPULAN}

Hasil penelitian yang diperoleh dalam penelitian Pengaruh Mekanisme Good Corporate Governance, Corporate Social Responsibility, dan Return On Asset terhadap Nilai Perusahaan adalah sebagai berikut:

1. Mekanisme Good Corporate Governance, Corporate Social Responsibility Disclosure, dan Return On Asset berpengaruh terhadap Nilai Perusahaan pada Perusahaan Perbankan Go Public yang Listed di BEI.

2. Dewan Direksi berpengaruh terhadap Nilai Perusahaan pada Perusahaan Perbankan Go Public yang Listed di BEI.

3. Dewan Komisaris berpengaruh terhadap Nilai Perusahaan pada Perusahaan Perbankan Go Public yang Listed di BEI.

4. Komite Audit berpengaruh terhadap Nilai Perusahaan pada Perusahaan Perbankan Go Public yang Listed di BEI.

5. Kepemilikan Institusional tidak berpengaruh terhadap Nilai Perusahaan pada Perusahaan Perbankan Go Public yang Listed di BEI.

6. Kepemilikan Manajerial berpengaruh terhadap Nilai Perusahaan pada Perusahaan Perbankan Go Public yang Listed di BEI.

7. Corporate Social Responsibility tidak berpengaruh terhadap Nilai Perusahaan pada Perusahaan Perbankan Go Public yang Listed di BEI.

8. Return On Asset berpengaruh terhadap Nilai Perusahaan pada Perusahaan Perbankan Go Public yang Listed di BEI. 
Anggi Adinda Setiarini, Pengaruh Mekanisme Tata Kelola Perusahaan yang Baik, Pengungkapan Tanggung Jawab Sosial Perusahaan, dan Pengembalian atas Penggunaan Asset Terhadap Nilai Perusahaan

\section{DAFTAR PUSTAKA}

Adnantara, Komang Fridagustina. 2013. Pengaruh Struktur Kepemilikan Saham dan Corporate Social Responsibility pada Nilai Perusahaan. Buletin Studi Ekonomi, 18(2): h: 107-113.

Bursa Efek Indonesia, www.idx.co.id,

Carniangsih, 2010. Pengaruh Good Corporate Governance Terhadap Hubungan Antara Kinerja Keuangan dengan Nilai Perusahaan (Studi Kasus Pada Perusahaan Property dan Real Estate yang Terdaftar di Bursa Efek Indonesia). Skripsi. Universitas Gunadarma

Gray, R.H.,et al, 1987, Corporate Social Resporting: Accounting and Accountability. London: Prentice-Hall International.

Ghozali, Imam, 2009, Aplikasi Analisis Multivariate Dengan Program SPSS, Edisi Keempat, Penerbit Universitas Diponegoro

Hamdani, 2016. Good Corporate Governance Tinjauan Etika Dalam Praktik Bisnis. Jakarta : Mitra Wacana Media

Handriyani, Arik Novia, 2013. Pengaruh Corporate Social Responsibility Terhadap Nilai Perusahaan Dengan Profitabilitas Sebagai Variabel Moderating. Jurnal Ilmu \& Riset Akuntansi Vol.2 No.5

Herawaty, 2008, Peran Praktek Corporate Governance sebagai Moderating Variabel dari Pengaruh Earnings Management Terhadap Nilai Perusahaan. Jurnal Akuntansi Dan Keuangan. Vol 10, No 2, November 2008: 97-108

Jehsen, Michael C. \& W.H. Meckling, 1976, Theory of the firm: managerial behavior, agency cost, and ownership structure, Journal of Financial Economics 3

Kasmir, 2008, Bank dan Lembaga Keuangan Lainnya. Edisi revisi 2008. Jakarta: PT.Raja Grafindo Persada

Margono, 2010, Metodologi Penelitian Pendidikan. Jakarta: Rineka Cipta

Mega, Fitri Mulianti, 2010, Analisis Faktor-Faktor Yang Mempengaruhi Kebijakan Hutang Dan Pengaruhnya Terhadap Nilai Perusahaan. Program Magister Manajemen Universitas Diponegoro 2010.

Munawaroh, Aisyatul. 2014. Pengaruh Profitabilitas Terhadap Nilai Perusahaan Dengan Corporate Social Responsibility Sebagai Variabel Moderating. Jurnal Ilmu \& Riset Akuntansi Vol.3 No.4

Murwaningsari, Etty, 2009, “Hubungan Corporate Governance, Corportate Social Responsibility dan Corporate Financial Performance Dalam Satu Continum. Jurnal Akuntansi Dan Keuangan. Vol. 11. No. 1. Mei.

Ni Wayan, Rustiarini. 2010, Pengaruh Corporate Governance pada Hubungan Corporate Social Responsibility dan Nilai Perusahaan. Simposium Nasional Akuntansi XIII. AKPM_12 
Anggi Adinda Setiarini, Pengaruh Mekanisme Tata Kelola Perusahaan yang Baik, Pengungkapan Tanggung Jawab Sosial Perusahaan, dan Pengembalian atas Penggunaan Asset Terhadap Nilai Perusahaan

Nugroho, Febry Setyo. 2013. Pengaruh Good Corporate Governance, Return On Assets dan Ukuran Perusahaan Terhadap Nilai Perusahaan Pada Perusahaan yang Terdaftar di BEI tahun 2008-2011. Skripsi. Fakultas Ekonomi Universitas Negeri Yogyakarta.

Permanasari, Wien Ika. 2010. Pengaruh Kepemilikan Manajemen, Kepemilikan Institusional, dan Corporate Social Responsibility terhadap Nilai Perusahaan. Skripsi Akuntansi Universitas Diponegoro Semarang.

Purwaningtyas, Frysa Praditha. 2011. Analisis Pengaruh Mekanisme Good Corporate Governance Terhadap Nilai Perusahaan. Skripsi. Jurusan Akuntansi Fakultas Ekonomi Universitas Diponegoro, Semarang.

Retno, Reny Dyah dan Denies Priantinah, 2012, Pengaruh Good Corporate Governance dan Pengungkapan Corporate Social Responsibility terhadap Nilai Perusahaan (Studi Empiris pada Perusahaan yang Terdaftar di BEI Periode 2007-2010). Jurnal Nominal Vol. 1 No. 2 Tahun 2012.

Rika Nurlela dan Islahuddin. 2008, Pengaruh Corporate Social Responsibility Terhadap Nilai Perusahaan Dengan Prosentase Kepemilikan Manajemen Sebagai Variabel Moderating (Studi Empiris Pada Perusahaan Yang Terdaftar di Bursa Efek Jakarta). Skripsi S1 Ekonomi. Universitas Syiah Kuala.

Sugiyono, 2010, Metode Penelitian Pendidikan Pendekatan Kuantitatif, Kualitatif dan RED. Bandung: Alfabeta

Susanto, Priyatna Bagus dan Imam Subekti, 2013. Pengaruh Corporate Social Responsibility dan Good Corporate Governance terhadap Nilai Perusahaan. http://jimfeb.ub.ac.id/index.php/jimfeb/article/viewFile/410/355. Diunduh 20 Oktober 2013

Sutedi Andrian, 2012, Good Corporate Governance, Cetakan Kedua, Penerbit Sinar Grafika, Jakarta.

Tri Sariri Muryati, Ni Nyoman dan I Made Sadha Suardhika. 2014. Pengaruh Corporate Governance Pada Nilai Perusahaan. Jurnal Akuntansi Universitas Udayana.

Undang-undang RI No. 10 Tahun 1998 tanggal 10 November tentang Perbankan, bank.

Yanuarti, Cintia. 2014. Pengaruh Good Corporate Governance Terhadap Kinerja dan Nilai Perusahaan High Profile yang Terdaftar di BEI tahun 2010-2013. Skripsi. Fakultas Ekonomi Universitas Negeri Yogyakarta. 